\title{
Association of CSSM066 and ILSTS011 microsatellite markers and thyroglobulin gene SNP with backfat in Canchim cattle
}

Gisele Batista Veneroni ${ }^{1}$, Sarah Laguna Meirelles², Henrique Nunes de Oliveira², Maurício Mello de Alencar ${ }^{3}$, Gustavo Gasparin ${ }^{1}$, João José de Simoni Gouveia ${ }^{4}$, Marcelo Cervini' ${ }^{1}$ Luciana Correia de Almeida Regitano ${ }^{3 *}$

'UFSCar - Depto. de Genética e Evolução, C.P. 676 - 13565-905 - São Carlos, SP - Brasil. 2UNESP/FCAV - Depto. de Genética e Melhoramento Animal, Via de Acesso Prof. Paulo Donato Castellane, s/n. - 14884-900 - Jaboticabal, SP - Brasil.

3Embrapa Pecuária Sudeste,

C.P. 339 - 13560-970 - São Carlos, SP - Brasil. ${ }^{4}$ UNIVASF/Colegiado Acadêmico de Zootecnia - Rod. BR 407, km 12 - 56300-990 - Petrolina, PE - Brasil.

*Corresponding author <luciana@cppse.embrapa.br>

Edited by: Gerson Barreto Mourão

Received May 27, 2010

Accepted June 04, 2011
ABSTRACT: Canchim, a synthetic breed of cattle derived from the Charolais and Zebu group has been used in the beef-cattle industry in Brazil as an alternative for intensifying production. One of the main concerns with this breed is its poor fat deposition and consequently, there is an effort to increase the performance for this trait. The thyroglobulin gene is located in a QTL region for fat deposition, and reports describe the influence of a polymorphism in the 5' leader sequence of that gene on marbling and subcutaneous fat thickness. This study analyzed the association of this polymorphism in the thyroglobulin gene, as well as of two flanking microsatellite markers, CSSM066 and ILSTS011, with backfat thickness in 987 Canchim beef cattle. The CSSM066 and ILSTS011 microsatellite markers have a effect on fat thickness in the studied populations. However, this trait did not have association with the polymorphism of the thyroglobulin gene, which suggests that other genes of bovine chromosome 14 may be responsible for the variation in this trait.

Keywords: Canchim breed, fat deposition, molecular markers, candidate gene

\section{Introduction}

Canchim (5/8 Charolais $+3 / 8 \mathrm{Zebu}$ ) and MA (offspring of Charolais bulls and 1/2 Canchim $+1 / 2$ Zebu cows) are genetic groups which have good growth potential and tropical adaptation; however, they have poor fat deposition under pasture management, with average fat thickness of $1.7 \mathrm{~mm}$ at the age of 18 months.

A QTL in the centromeric region of BTA14 (Bos taurus chromosome 14) was described for backfat thickness (BF) (Casas et al., 2000; Moore et al., 2003). The thyroglobulin gene (TG) was mapped in this region (Threadgill et al., 1990) and it has been indicated as a candidate gene for fat deposition traits in beef cattle (Barendse et al., 2001; Gan et al., 2008; Casas et al., 2005 and Wood et al., 2006).

Thyroglobulin is a glycoproteic hormone that is synthesized by the thyroid follicular cell and is the precursor for triiodothyronine (T3) and thyroxin (T4), which have been associated with marbling deposition in Wagyu cattle (Mears et al., 2001). The thyroidean hormones affect intestinal glucose absorption and insulin-mediated acquisition of glucose by the cells, adipocyte growth and differentiation (Ailhaud et al., 1992). In general, the effect of thyroidean hormones on metabolic processes is catabolic (Pucci et al., 2000). A polymorphism in the $5^{\prime}$ leader sequence (Tg5) of the TG gene was associated with marbling and the 3' allele was more common in animals with higher marbling (Barendse et al., 2001). This marker is the basis of the commercial test Gene Star Marbling ${ }^{\mathrm{TM}}$ (Pfizer Animal Health).

In this study, one analyzed the association of two microsatellite markers, CSSM066 and ILSTS011, flank- ing the thyroglobulin gene, and of Tg5 polymorphism of the TG gene with BF in Canchim and MA populations.

\section{Materials and Methods}

A total of 987 Canchim animals of known pedigree, belonging to half-sib families (progeny of 113 bulls), males and females, raised in pasture, born between 2003 and 2005 were evaluated for backfat thickness at the age of 18 months. Animals born in 2003 and 2004 belonged to

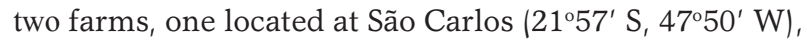
state of São Paulo, Brazil, and the other located at Jussara $\left(15^{\circ} 55^{\prime} \mathrm{S}, 50^{\circ} 50^{\prime} \mathrm{W}\right)$, state of Goiás, Brazil. Animals born in 2005 were from five farms situated in the state of Sao Paulo in addition to the two farms sampled in previous years.

Animals belonged to combinations of sire and dam genetic groups: offspring from Charolais $\times 1 / 2$ Canchim $+1 / 2$ Nelore were classified as the MA genetic group. The Canchim genetic group (CA) was composed of products from $\mathrm{MA} \times \mathrm{MA}, \mathrm{CA} \times \mathrm{MA}$ and $\mathrm{CA} \times \mathrm{CA}$ mating pairs. Measures of fat thickness were obtained by image analysis using the Piemedical Scanner 200 Vet ultrasound equipment, and a $3.5 \mathrm{MHz}, 18-\mathrm{cm}$ long, linear array probe, or with the equipment ALOKA $500 \mathrm{~V}$, with a linear probe of $17.2 \mathrm{~cm}$ and $3.5 \mathrm{MHz}$. Measures were taken at the back of the lumbar region, between the $12^{\text {th }}$ and $13^{\text {th }}$ ribs.

Blood samples of $5 \mathrm{~mL}$ were collected from every animal. Whenever available, semen samples were also collected from the sires for confirmation of paternity. DNA was extracted using a standard salting out procedure and quantified in a spectrophotometer.

Sires and progenies were genotyped for the three molecular markers chosen by their positions on the maps 
deposited at the NCBI, 2005 Gene Bank. The two microsatellite markers, CSSM066 and ILSTS011, located at 3.9 $\mathrm{Mb}$ and $11.8 \mathrm{Mb}$, respectively, on BTA14, were chosen to flank the thyroglobulin gene $(7.8 \mathrm{Mb})$. The other marker chosen was Tg5, a polymorphism (C/T substitution) that occurs in the $5^{\prime}$ leader sequence of the thyroglobulin gene (Barendse et al., 2001).

The CSSM066 and ILSTS011 microsatellites were amplified by the polymerase chain reaction (PCR) in a final volume of $13.5 \mu \mathrm{L}$ containing $40 \mathrm{ng}$ of genomic DNA, $0.2 \mu \mathrm{M}$ of each primer, $50 \mathrm{mM} \mathrm{KCl}, 1.5 \mathrm{mM} \mathrm{MgCl}_{2}, 10$ $\mathrm{mM}$ Tris- $\mathrm{HCl} \mathrm{pH} 8.4,0.2 \mathrm{mM}$ dNTPs and $0.25 \mathrm{U}$ Taq polymerase. Reactions were carried under the following conditions: initial denaturation at $94{ }^{\circ} \mathrm{C}$ for $3 \mathrm{~min}$, followed by 28 cycles of denaturation at $94{ }^{\circ} \mathrm{C}$ for $30 \mathrm{~s}$, annealing at $59{ }^{\circ} \mathrm{C}$ for $30 \mathrm{~s}$, extension at $72{ }^{\circ} \mathrm{C}$ for 30 sec and a final extension for $45 \mathrm{~min}$. Primer sequences were as described in the (MARC, 2005) database and forward primers were labeled with fluorescent dye in the $5^{\prime}$ end. PCR products were analyzed in an automatic DNA sequencer ABI 3100 Avant (Applied Biosystems). Genotypes were determined using the GeneScan (version 3.7.1) and Genotyper (version 3.7) software.

The Tg5 polymorphism was genotyped through restriction analysis of PCR products (PCR-RFLP). The 546 bp that comprise the $5^{-}$leader sequence of the thyroglobulin gene were amplified using primers as described in Barendse (1997). PCR was performed using $100 \mathrm{ng}$ of genomic DNA in a final reaction volume of $25 \mu \mathrm{L}$, containing $10 \mathrm{mM}$ Tris- $\mathrm{HCl} \mathrm{pH} \mathrm{8.3,} 1.95 \mathrm{mM} \mathrm{MgCl}_{2}$, $50 \mathrm{mM} \mathrm{KCl}, 200 \mu \mathrm{M}$ of each dNTP, $0.165 \mu \mathrm{M}$ of each primer and $0.65 \mathrm{U}$ Taq DNA polymerase. The amplification consisted of initial denaturation at $94{ }^{\circ} \mathrm{C}$ for 2 min, followed by 35 cycles at $94{ }^{\circ} \mathrm{C}$ for $30 \mathrm{~s}$, annealing temperatures at $55{ }^{\circ} \mathrm{C}$ for $30 \mathrm{~s}$, and extension at $72{ }^{\circ} \mathrm{C}$ for $30 \mathrm{~s}$. After 35 cycles, the amplified product was submitted to a final extension for $10 \mathrm{~min}$. The PCR product was digested with the $\mathrm{MboI}$ restriction endonuclease in a reaction that consisted of $15 \mu \mathrm{L}$ of the PCR product and $1 \mathrm{U}$ (unit) $M b o I$ with buffer in a final volume of $17 \mu \mathrm{L}$. The digestion reactions were incubated at $37^{\circ} \mathrm{C}$ for 3 hours and fragment pattern was determined by agarose gel electrophoresis.

The Genepop software (Raymond and Rousset, 1995; Rousset, 2008) was used to test the existence of linkage disequilibrium (LD) between the three markers studied. The null hypothesis was "Genotypes at one locus are independent from genotypes at the other locus".

Associations between marker genotypes and measures of BF were analyzed using the restricted maximum likelihood method. In these analyses, performed using the ASREML software (Gilmour et al., 2000) according to Schenkel et al. (2005), 32 contemporary groups (CG) were created with the variables: birth year, herd, genetic group (CA or MA) and sex. The CGs with less than two individuals were excluded from the subsequent analysis. To verify the influence of the molecular markers on fat thickness, a model considered the CG and marker geno- types as fixed effects, and the age of the animal at measurement (linear) as covariate, in addition to the direct additive genetic and the residual effects.

Every analysis was performed individually for each of the 3 markers. Alleles and genotypes that presented frequency lower than $1 \%$ were excluded from all analyses.

The statistical model used was: $\mathbf{y}=\mathbf{X} \beta+\mathbf{Z a}+$ $\mathbf{e}$, in which $\mathbf{y}$ is the observation vector; $\mathbf{X}$ is the contemporary group incidence matrix; $\beta$ is the fixed effects vector (contemporary group, age and genotypes); $\mathbf{Z}$ is the incidence matrix that relates the registries to the random genetic effects; $\mathbf{a}$ is the vector of the random genetic effects that represent the breeding value of each animal; $\mathbf{e}$ is the random error vector.

The effect of allele substitution, as deviation of the allele with the highest frequency, was estimated by replacing the genotype effect by covariables (as fixed effect) in the model described above, representing the number of each allele in the genotype when a $(p \leq 0.05)$ marker genotype effect was observed. This analysis also provides us with an estimate of the effect of each allele on the phenotype in relation to the effect of the more frequent alleles.

To test for the presence of dominant deviations from the additive model, a comparison between the model containing the marker genotypes (complete model) and the model used in the analysis of allelic substitution effects (reduced model) was performed by the likelihood ratio test (Mood et al., 1974).

\section{Results and Discussion}

CSSM066 and ILSTS011 microsatellite markers presented 14 and eight alleles respectively in the population studied and the $\operatorname{Tg} 5$ polymorphism presented two alleles. After the exclusion of the alleles and genotypes with frequency equal or inferior to $1 \%, 11$ and five alleles were kept for CSSM066 and ILSTS011 microsatellite markers respectively and the Tg5 remained as before. Allelic frequencies for the animals considered in the association analysis of the three markers are presented in Table 1. The allelic combinations of the CCSM066

Table 1 - Allelic frequencies of CSSM066, Tg5 and ILSTS011 markers.

\begin{tabular}{|c|c|c|c|c|c|}
\hline \multicolumn{2}{|c|}{ CSSM066 } & \multicolumn{2}{|r|}{ Tg5 } & \multicolumn{2}{|c|}{ ILSTS011 } \\
\hline Allele & Frequency & Allele & Frequency & Allele & Frequency \\
\hline & $\%$ & & $\%$ & & $\%$ \\
\hline 178 & 15.60 & 1 & 16.33 & 260 & 22.51 \\
\hline 180 & 11.06 & 2 & 83.67 & 262 & 2.56 \\
\hline 182 & 23.55 & . & . & 264 & 4.79 \\
\hline 184 & 21.35 & . & . & 266 & 25.07 \\
\hline 186 & 0.71 & . & . & 268 & 45.08 \\
\hline 188 & 6.10 & . & . & . & . \\
\hline 190 & 1.84 & . & . & . & . \\
\hline 192 & 13.48 & . & . & . & . \\
\hline 196 & 1.13 & . & . & . & . \\
\hline 198 & 5.18 & . & . & . & . \\
\hline
\end{tabular}


marker resulted in 31 genotype classes, and the allelic combinations of the ILSTS011 marker resulted in 11 genotype classes.

Markers were chosen based on proximity to the thyroglobulin gene assuming that this gene influences fat deposition in bovine carcass. Polymorphism in the thyroglobulin gene was not associated with backfat thickness in the present data $(p>0.05)$ and the allele described as favorable for high marbling (Barendse et al., 2001), designated in that study as allele 1, was found in the Canchim breed at a frequency of $16.33 \%$ (Table 1 ), which is not low. The polymorphism in the $5^{\prime}$ leader sequence of the thyroglobulin gene was associated with intramuscular fat deposition in beef cattle (Barendse et al., 2001; Gan et al., 2008; Wood et al., 2006) and Casas et al. (2005) found association of this polymorphism with fat thickness in a Brahman population, but not with marbling score; however, it could not be concluded that there was a direct effect of the TG gene on that work.

The absence of a detectable effect of Tg5 on backfat may be attributed to differences among the beef cattle populations used in each study, as well as to the environment, management and diet in which the effect was studied (Rincker et al., 2006). If one considers that the previously reported association with fat deposition results from linkage disequilibrium with the gene truly responsible for the variation in this trait, linkage disequilibrium (LD) status in each population could also explain differences regarding the Tg5 effect. As only the effect of Tg5 on subcutaneous fat thickness was tested one cannot discard a possible effect on marbling, since the correlation between these two traits is not very high (Crews and Kemp, 2001). The results obtained for Canchim were similar to the results of studies of Moore et al. (2003), who did not identify association between this candidate gene and estimated breeding value (EBV) for fat thickness.

The CSSM066 and ILSTS011 microsatellite markers presented a effect $(p \leq 0.05)$ on fat thickness of Canchim. They are located in the centromeric region on BTA14 where QTL for fat thickness were described (Casas et al., 2000; Moore et al., 2003). Moore et al. (2003) found association between backfat EBV and the CSSM066 locus. The fact that the two Tg5 flanking microsatellite markers had a contribution on the variation of BF whereas Tg5 did not is supported by the result of LD test, which demonstrates that the two microsatellites are in LD with each other but neither one is in LD with $\operatorname{Tg} 5$. Taken together, the effect of two flanking markers and the absence of LD among these markers and Tg5 may suggest that both microsatellites are in disequilibrium with one or more genes that influence this trait other than TG. Lee et al. (2007) demonstrated that the LD between microsatellites is different from the LD between SNPs. These differences are presumably caused by high rates of mutation and heterozygosity of microsatellites in relation to SNPs, with the latter presenting lower evolution rate and less instability and, therefore, it is not possible to compare microsatellite LD maps and SNP LD maps.

The analysis of allele substitution allows calculation of the direct effect of each allele through a model that considers the average additive effect of an allele in the population. The 260 and 184 alleles from ILSTS011 and CSSM066 markers revealed significant $(p<0.05)$ and suggestive $(p \leq 0.1)$ effects respectively (Table 2), suggesting that the animals containing these alleles also carry alternative alleles from a linked QTL that contributes to the variation of backfat. The 260 allele from the ILSTS011 marker increased the average fat thickness of the homozygote 268 by $0.08 \mathrm{~mm}$ in the population studied and the 184 allele from the CSSM066 marker decreased the average fat thickness of the homozygote 182 by $0.95 \mathrm{~mm}$ (Table 2 ).

The complete model (genotype as fixed effect) was not different $(p>0.05)$ from the reduced model (alleles as covariates) according to the likelihood ratio test. From this result it is possible to conclude that the marker effects were predominantly additive, with no deviations attributable to dominance or epistasis, a desired situation for marker assisted selection.

Mutations in the thyroglobulin gene may not be the cause of differences in fat thickness in cattle, but rather mutations in other genes close to TG. Several genes involved in lipid metabolism and adipocyte differentiation located on BTA14 have been suggested as candidate genes influencing fat deposition traits in cattle. A mutation in the diacilglicerol aciltransferase gene (DGAT1) was indicated as the causative mutation for differences in milk fat percentage (Winter et al., 2002). Riquet et al. (1999) described the presence of QTLs for that trait in this region of BTA14 in dairy cattle. However, Moore et al. (2003) did not find association between DGAT1 and fat thickness EBV. Wibowo et al. (2007) found an effect of some SNPs of corticotropin gene on subcutaneous fat depth and marbling in beef cattle. Michal et al. (2006) showed that the FABP 4 affected marbling and subcuta-

Table 2 - Results from analysis of the effect of allele substitution, as deviation of the allele with the highest frequency, of CSSM066 and ILSTS011 microsatellites, on backfat thickness of Canchim.

\begin{tabular}{lccccccccc}
\hline \multicolumn{3}{c}{ CSSM066 marker } & & \multicolumn{5}{c}{ ILSTS011 marker } \\
\cline { 1 - 6 } \cline { 7 - 9 } Effect & DF & $p$ value & AEE & & Effect & DF & $p$ value & AEE \\
\hline Mean & 1 & $<0.01$ &. & & Mean & 1 & $<0.01$ &. \\
CG & 32 & $<0.01$ &. & & CG & 32 & $<0.01$ &. \\
178 & 1 & 0.478 & -0.39 & & 260 & 1 & 0.023 & 0.08 \\
180 & 1 & 0.911 & 0.07 & & 262 & 1 & 0.809 & 0.02 \\
184 & 1 & 0.067 & -0.95 & & 264 & 1 & 0.478 & 0.05 \\
186 & 1 & 0.567 & -1.15 & & 266 & 1 & 0.129 & 0.05 \\
188 & 1 & 0.324 & -0.78 & & Age & 1 & $<0.01$ &. \\
190 & 1 & 0.577 & 0.70 & & & & \\
192 & 1 & 0.753 & -0.17 & & & & \\
198 & 1 & 0.456 & -1.17 & & & & \\
Age & 1 & $<0.01$ &. & & & & \\
\hline
\end{tabular}

$\mathrm{CG}=$ contemporary groups $; \mathrm{DF}=$ Degree of Freedom; $\mathrm{AEE}=$ Allele effect estimate (mm). 
neous fat depth in Wagyu $\times$ Limousin F2 crosses and Cho et al. (2008) associated polymorphisms in FABP4 with backfat traits. The development and differentiation enhancing factor 1 gene (DDEF1) located at 9.7 Mb on BTA14 is related to adipogenesis (King et al., 1999). King et al. (1999) purified and cloned the DDEF1 protein of bovine brain cells and observed that the expression of this protein resulted in the differentiation of fibroblasts in adipocytes in vitro and Veneroni et al. (2010) found a effect $(p \leq 0.05)$ of allele substitution of an SNP in the DDEF1 gene on backfat thickness in Canchim cattle.

Several works reported the existence of a QTL for backfat thickness in centromeric region of BTA14 (Moore et al., 2003; Casas et al., 2000) and the present study found association of this trait with the CSSM066 and ILSTS011 markers, but not with Tg5. Other genes located on BTA14 (CRH, FABP4, DDEF1) may be selected for future studies as potential candidates that influence fat deposition variation in this population.

\section{Acknowledgements}

To Ipameri Agricultural Group and Embrapa Pecuária Sudeste, for providing phenotypic data and blood samples of animals. To CAPES /Coordenação de Aperfeiçoamento de Pessoal de Nivel Superior) and to CNPq (Conselho Nacional de Desenvolvimento Científico e Tecnológico), for providing scholarships.

\section{References}

Ailhaud, G.; Grimald, P.; Negrel, R. 1992. Cellular and molecular aspects of adipose tissue development. Annual Review of Nutrition 12: 207-233.

Barendse, W. Assesing lipid metabolism. 1997. Patent Application (WO9923248 PCT/AU98/00882). Available at: http://ep.espacenet. com/ [Accessed Mar. 27, 2003]

Barendse, W.; Bunch, R.; Thomas, M.; Armitage, S.; Baud, S.; Donaldson, N. 2001. The Tg5 DNA marker test for marbling capacity in Australian feedlot cattle. Available at: http://www. Beef.crc.org.au/Publications/Marblingsym/Day 1/Tg5 DNA [Accessed Mar. 9, 2003]

Casas, E.; Shackelford, S.D.; Keele, J.W.; Stone, R.T.; Kappes, S.M.; Koohmaraie, M. 2000. Quantitative trait loci affecting growth and carcass composition of cattle segregating alternate forms of myostatin. Journal of Animal Science 78: 560-569.

Casas, E.; White, S.N.; Riley, D.G.; Smith, T.P.L.; Brenneman, R.A.; Olson, T.A.; Johnson, D.D.; Coleman, S.W.; Bennett, G.L.; Chase Jr., C.C. 2005. Assessment of single nucleotide polymorphisms in genes residing on chromosomes 14 and 29 for association with carcass composition traits in Bos indicus cattle. Journal of Animal Science 83: 13-19.

Cho, S.; Park, T.S.; Yoon, D.H.; Cheong, H.S.; Namgoong, S.; Park, B.L.; Lee, H.W.; Han, C.S.; Kim, E.M.; Cheong, I.C.; Kim, H., Shin, H.D. 2008. Identification of genetic polymorphisms in FABP 3 and $\mathrm{FABP} 4$ and putative association with back fat thickness in Korean native cattle. BMB Reports 41: 29-34.
Crews Jr., D.H.; Kemp, R.A. 2001. Genetic parameters for ultrasound and carcass measures of yield and quality among replacement and slaughter beef cattle. Journal of Animal Science 79: 3008-3020.

Gan, Q.; Zhang, L.; Li, J.; Hou, G.; Li, H.; Gao, X.; Ren, H.; Chen, J.; Xu, S. 2008. Association analysis of thyroglobulin gene variants with carcass and meat quality traits in beef cattle. Journal of Applied Genetics 49: 251-255.

Gilmour, A.R.; Cullis, B.R.; Welham, S.J.; Thompson, D.R. 2000. ASREML Reference Manual. IACR-Rothamsted Experimental Station, Harpenden, UK.

King, F.J.; Hu, E.; Harris, D.F.; Sarraf, P.; Spiegelman, B.M.; Roberts, T.M. 1999. DEF-1, a novel Src SH3 binding protein that promotes adipogenesis in fibroblastic cell lines. Molecular and Cellular Biology 19: 2330-2337.

Lee, K.A.; Sohn, K.M.; Cho, S.H.; Hwang, H.; Kim, S.W.; Won, H.H.; Kim, H.J.; Kim, M.; Cho, S.S.; Park, J.H.; Kim, J.W. 2007. Distinct linkage disequilibrium (LD) runs of single nucleotide polymorphisms and microsatellite markers: implications for use of mixed marker haplotypes in LD-based mapping. Journal of Korean Medical Science 22: 425-430.

Mears, G. J.; Mir, P.S.; Bailey, D.R.C.; Jones P.M. 2001. Effect of Wagyu genetics on marbling, backfat, and circulating hormones in cattle. Canadian Journal of Animal Science 81: 65-73.

Meat Animal Research Center. [MARC]. MARC database. Available at: http://www.marc.usda.gov [Accessed Mar. 20, 2005]

Michal, J.J.; Zhang, Z.W.; Gaskins, C.T.; Jiang, Z. 2006. The bovine fatty acid binding protein 4 gene is associated with marbling and subcutaneous fat depth in Wagyu x Limousin F2 crosses. Animal Genetics 37: 400-402.

Mood, A.M.; Graybill, F.A.; Boes, D.C. 1974. Tests of hypotheses. p. 401-470. In: Mood, A.M.; Graybill, F.A.; Boes, D.C., eds. Introduction to the theory of statistics. McGraw-Hill, Tokyo, Japan.

Moore, S.S.; Li C.; Basarab, J.; Snelling, W.M.; Kneeland, J.; Murdoch, B.; Hansen, C.; Benkel, B. 2003. Fine mapping of quantitative trait loci and assessment of positional candidate genes for backfat on bovine chromosome 14 in a commercial line of Bos taurus.Journal of Animal Science 81: 1919-1925.

National Center for Biotechnology Information [NCBI] Gene bank. Available at: http://www.ncbi.nlm.nih.gov [Accessed Mar. 27, 2005]

Pucci, E.; Chiovato, L.; Pinchera, A. 2000. Thyroid and lipid metabolism.International Journal of Obesity 24: 109-112.

Raymond, M.; Rousset F., 1995. GENEPOP (version 1.2): population genetics software for exact tests and ecumenicism. Journal of Heredity 86: 248-249

Rincker, C.B.; Pyatt, N.A.; Berger, L.L.; Falkher, D.B. 2006. Relationship among GeneSTAR marbling marker, intramuscular fat deposition, and expected progeny differences in early weaned Simmental steers. Journal of Animal Science 84: 686-692.

Riquet, J.; Coppieters, W.; Cambisano, N.; Arranz, J.J.; Berzi, P.; Davis, S.K.; Grisart, B.; Farnir, F.; Karim, L.; Mni, M.; Simon, P.; Tayor, J.F.; Vanmanshoven, P.; Wagenaar, D.; Womack, J.E.; Georges, M. 1999. Fine-mapping of quantitative trait loci by identity by descent in outbred population: Application to milk production in dairy cattle. Proceedings of the National Academy of Sciences of the United States of America 96: 9252-9257. 
Rousset, F. 2008. Genepop'007: a complete reimplementation of the Genepop software for Windows and Linux. Molecular Ecology Resources 8: 103-106.

Schenkel, F.S.; Miller, S.P.; Moore, S.S.; Nkrumah, J.D.; Li, C.; Yu, J.; Mandell, I.B.; Wilton, J.W.; Williams, J.L. 2005. Association of single nucleotide polymorphisms in the leptin gene with carcass and meat quality of beef cattle. Journal of Animal Science 83: 2009-2020.

Threadgill, D.W.; Fries, R.; Faber, L.K.; Vassart, G.; Gunawardana, A.; Stranzinger, G.; Womack, J. 1990. The thyroblobulin gene is syntenic with the MYC and MOS proto-oncogenes and carbonic anhydrase II and maps to chromosome 14 in cattle. Cytogenetics and Cell Genetics 53: 32-36.

Veneroni, G.B.; Meirelles, S.L.; Grossi, D.A.; Gasparin, G.; Ibelli, A.M.; Tizioto, P.C.; Oliveira, H.N.; Alencar, M.M.; Regitano, L.C. 2010. Prospecting candidate SNPs for backfat in Canchim beef cattle. Genetics and Molecular Research 9: 1997-2003.
Wibowo, T.A.; Michal, J.J.; Jiang, Z. 2007. Corticotropin releasing hormone is promising candidate gene for marbling and subcutaneous fat deph in beef cattle. Genome 50: 939-945.

Winter, A.; Kramer, W.; Werner, W.A. O.; Kollers, S.; Kata, S.; Durstewitz, G.; Buitkamp, J.; Womack, J.E.; Thaller, G.; Fries R. 2002. Association of a lysine-232/alanine polymorphism in a bovine gene encoding acyl-CoA:diacylglycerol aciltransferase (DGAT1) with variation at a quantitative trait locus for milk fat content. Proceedings of the National Academy of Sciences of the United States of America 99: 9300-9305.

Wood, I.A.; Moser, G.; Burrell, D.L.; Mengersen, K.L.; Hetzel, D.J.S. 2006. A meta-analytic assessment of a Thyroglobulin marker for marbling in beef cattle. Genetics, Selection, Evolution 38: 479-494. 